\title{
REFORMATION IN LEARNING HISTORY
}

\section{Suranto ${ }^{1}$}

\begin{abstract}
Learning history in school have benefit for life and for the nation and state itself. Learning history can evoke a sense of history and national consciousness, but the reality that there is less functional and even become a boring subject. Various reformation efforts have been made, but has not shown significant result, therefore, necessary reforms. These reforms were carried out with a systemic reform, changing the mindset about learning the history and unite the steps of all parties concerned, including decision makers. Renewal in learning the history of applied learning model that develops students intellectually. Through this model of learning is expected to be more attractive and functioning properly.
\end{abstract}

Key words: reformation, learning history

\section{Introduction}

The role and status of teaching history would be no doubt, both for students and the continuity of the life of nation and state. The role and status of this history is not only recognized by historians, but also many figures from various circles in this world. Cicero, a Greek philosopher who believes that history includes the past experiences of humankind is full of lessons about life that can be used as a means to achieve certain educational goals desired human. Therefore he said that the Historia Magistra Vitae (Ankersmit, 1987). History can teach humanity experiences a high value that can be used as a guide and view of life in the face of life and determine and plan for life in the future. By studying history at least someone is not going to fall twice in the same hole.

In line with these opinions, Nehru India's leader said: "We Can not leave Begins with our own history of life (Tamburaka, 1993). Similar opinion was expressed by Confutse, a famous philosopher from China. He said that history teaches us all to act wisely (Tamburaka, 1993). This opinion seems more popular and already proven by many experts who argued the same, like Sieley and Hill (1956). Linked to national educational goals, learning history has an important role, especially in developing nations that dignified civilization (Kartodirdjo, 1989), increased the intellectual life of nation (Anhar Gonggong, 2006), and form democratic citizens and responsible.

Based on history learning and memory function of learning history in Indonesia have been conducted since the Dutch colonial government, the people of

\footnotetext{
1 Dr. Suranto is lecturer at the Departement of History Education, Jember University. This article has been reviewed by Prof. Dadang Supardan, M.Pd (Indonesia University of Education) and Prof. Said Hamid Hasan (Indonesia University of Education), and Prof. Dato Qasim Ahmad (UiTM Malaysia).
} 
Indonesia should have formed an intelligent, wise, and have a sense of nationalism in Indonesia achieve national goals. In other words, should have realized a strong unitary state under the rule of a strong, just and prosperous society. Reality suggests that the opposite condition, such as poverty, social inequality, the threat of disintegration, and the government less stable. The condition was more disturbing is the existence of mental corruption of the organizers of the country (Kwik Kian Gie, 2002).

This condition is worried and as an example of the indication of the failure of the learning process in school history. This was acknowledged by historian Indonesia Sartono Kartodirjo who feel concerned for the implementation of teaching history in schools and according to the aspirations and the inspiration of the students would not be expected to grow and develop if the implementation of teaching history in schools as it is now ( Kartodirdjo, 1996). Concerns about the implementation of this history lesson, also expressed by Djoko Surjo (1989), which says that the implementation of teaching history in secondary schools in Indonesia has experienced deterioration in its day to day. According to Koller, as quoted by Haikal (1989), says that students felt very boring when learning history in school, because the learning process more emphasis on a wide range of material than its depth.

Deterioration of learning history at school should not occur, because the improvement efforts have been made by the Indonesian government. These efforts, standardizing the education with various consequences. In terms of curriculum, the government had made several reforms, so that the known number of curriculum with individual characteristics, such as: curricula 1968, curriculum 1975, Curriculum 1984, the 1994 curriculum, competency-based curriculum (KBK), and the last is a curriculum unit level education (KBK). With a spate of curriculum reform in schools should be learning, including learning history made progress and learning objectives can be realized.

By looking at the existing conditions of life, indicates that various efforts to reform and improve the quality of teaching in schools has not met its goals. Based on the research that has been done, suggests that curriculum reform has been done with only changed the administrative system of learning tools but not changed the learning process (Suranto, 2000). Government's efforts to implement the standardization of education is a concrete manifestation in improving the quality of education in schools, but the reality is that effort just to change the system of teacher administration of planning activities to determine students' graduation, while the learning process by teachers, especially in the learning of history remained limited to efforts to deliver a series of historical material to students (Suranto, 2009).

Various efforts to reform and improve the learning quality by the government but have not show significant effect that the reform efforts undertaken not systemic, that only covers some of the existing components and can even be said that the only half-hearted effort. In connection with this matter, then in 
an attempt to reform history teaching in schools to increase the goal of history is necessary systemic changes, comprehensively covering all the components associated with the learning process in school history and the fundamental. In other words, in improving the quality of history teaching in schools is needed reforms.

This paper tries to study and offer some form of renewal of learning the history of the systemic and fundamental, so-called reform of history teaching in schools. Renewal is done with the intent to improve the effectiveness of teaching history to realize the true intention.

This study is based on research results and the presentation of this study will be preceded by exposure of the reality of learning in school history that underlies the need for reform in teaching history. Then in a row will be explained the framework of alternative models of learning history and learning history as a form of reform.

\section{Reality Learning History in Schools}

Learning history in schools in Indonesia have been conducted since the Dutch colonial era (Klooster, 1992). After Indonesian independence, the history of the subjects included in the school curriculum from elementary school until high school. On his way, pendidilkan in Indonesia has experienced several replacements curriculum with the characteristics respectively. Curriculums that applies include: curriculum 1968, 1975, 1984, 1994, competency-based curriculum (KBK), and Education Unit Level Curriculum (KTSP). Curriculum changes are a manifestation of the government's efforts in improving the quality of education, so that quality education should be increased. This condition is apparently not applicable in the learning of history, because various studies indicate that learning history in school longer and far more alarming than the expected goals (Sartono Kartodirdjo, 1993)

New curriculum which applies in the implementation of Education in school is SBC. This curriculum was developed based on the spirit of regional autonomy, hiterogenitas citizens, and the uniqueness of potential learners. Each school was given the freedom to develop its own curriculum in accordance with the conditions and potential of the school and its environment. In order to guarantee the quality of education of each school, the government set minimum standards that must be met by each school. In this case there are eight standards: (1) content standards, (2) standard process, (3) competency standards, (4) standards of educators and education personnel, (5) the standard of facilities and infrastructure, (6) management standards ; (7) financing standards, and (8) assessment standards of education.

In Ministerial Education No. 22 of 2006 concerning the content standards set learning goals, standards of competence and basic competence from their 
respective subjects and educational unit, as well as provisions related to promotes learning activities. Thus, the standard content that becoming base in developing the school curriculum in every subjects, including subjects of history.

When associated with the nature of learning history, the provisions contained in the content standards, especially for high school history subjects has some weaknesses:

1. The purpose of learning about the history leading to the core of the purpose of learning history, the history of self-awareness that enables learners are able to find the values of historical events and apply them in everyday life.

2. The standard of competence that exist tend to be more oriented towards the subject matters or delivery of course material. The formulation of competency standards is certainly less appropriate and less realizeable the purpose of learning history, and even will result in making history as the memorization subjects are boring and no benefits.

3. There is a distinction allocations of learning time in class XI and XII of the program students social studies, science and language. This distinction is further emphasized that the direction of learning history outlined in the Ministerial Education No. 22 of 2006 is more oriented subject matters. This is evident in the formulation of standards of competence, namely the formulation of competency standards for science and language programs only merger or compaction some competency standard formulation of the Social science program. Compaction is not followed by a reduction in scope and subject matter, so the scope and subject matter between Social science programs, science and language remains the same. This condition will certainly be a burden on classroom teachers administer science and language programs, because the allocation of time is limited compared with the Social science program. This is evident in the observations in some high school, which teachers administer the Science program was pursued target subject matter that much with the allocation of limited time. This lead to the implementation of learning merely delivering course material. Differentiation allocations of learning time in class XI and XII of the program students social studies, science and language also shows that the direction of learning in high school history education is not a history but a history of restricted materials science studies.

Another weakness of the government's policy regarding the teaching of history in high school appear in the formulation of Competency Standards Graduates (SKL) Subject as stated in the Ministerial History Education No. 23 of 2006. SKL formulation appeared more mastery of their subject matter (subject matters oriented) and not on finding the values of historical events as a form of historical consciousness to be applied in everyday life.

SKL as a guide teachers in determining students' graduation course will have broad impact on the learning process. SKL which are subject matters tend to be more oriented course will encourage teachers to put more emphasis on the delivery of course material so that students have the ability in accordance 
with the demands of SKL. As a result of learning will be less in accordance with the provisions of the standards process. Learning conditions in school history the farther from the expectation after the Head Curriculum (PUSKUR) issued a syllabus of subjects. Syllabus issued PUSKUR got a pretty good response from teachers. They're not just making it as a guide in developing the syllabus in their schools, but many of the teachers who make it as a syllabus subject in their schools. The results showed that there are several reasons the teachers use the syllabus PUSKUR publications, namely: (a) PUSKUR, regarded as the institution responsible for curriculum development, so the results are more reliable and feasible will become a reference in execution of Final Exam, both national final examination (UAN) and the final exam School (UAS), (b) Syllabus PUKUR issue seems more complete, making it easy and pamper even the teacher in making the syllabus; (c) Syllabus PUKUR publications adopted in full by a publisher and made the basis in developing teaching materials, so for teachers who use it will experience no difficulty in finding and developing course material.

When studied in depth syllabus PUSKUR publications, especially for the subjects of History at the high school subject matters very nature oriented. This is evident in the formulation of indicators and learning activities. With the lessons of history in high school that uses a syllabus published by PUSKUR possible only emphasizes the effort of course materials that will be further away from achieving the objective nature of history lesson.

Explanation shows the inconsistency of government policy in the implementation of learning history. The policy set out in Ministerial Education number 22 in 2006, Ministerial Education number 23 in 2006, and the issuance by Puskur syllabus, making the learning of history tends towards subject matters oriented. Learning of this kind will not support the achievement of learning goals of history, the application of the five pillars of education, and limited support for the achievement of national education goals. Thus it can be said that these policies led to the implementation of teaching history in schools, especially the high school system defects. This condition causes the learning of history in schools worse off, unable to achieve expected goals, and even become a boring subject and slighted.

The observation of the conduct of learning history in high school who have applied SBC among other things: (1) teachers' learning goals formulated in a unit of lesson programs tend to be more oriented subject matters, (2). Learning is done by delivering subject material in accordance with the load is written in the curriculum, (3) the learning process is done by lecture method and occasionally punctuated with a question and answer, discussion and assignment, (4) learning media used is a handle student textbook, (5) evaluation conducted to measure the mastery of the material that has been given, (6) most history teachers lack the ability in mastering the concept of learning history, develop course material, and lacked insight into the history, values and culture; (7) less interesting, less encouraging students to learning, boring, and even makes the students 
underestimated; (8) history lessons come alive, interesting and working properly when executed by a professional teacher who is always willing to improve the way the lesson (Suranto, 2008).

The reality of this history lesson was also happening in other areas, such as in high school Bali (Suwita, 1990), even happen in Jakarta (Suranto, 2008). The condition was more disturbing happened in history in high school learning in Pati regency, which is done by giving the notes in accordance with teachers' handbook (Sayono, 1995). At first glance, the general weakness in the teaching of history lies in the use of learning strategies, which tend to only use the lecture method monotonically to convey the facts of history. However, when studied in depth many of the factors that helped influence it. Is an influential factor is the school curriculum. In that school curriculum is a teacher in implementing the guidelines and develop learning includes learning objectives that tend to be oriented subject matters. The formulation of learning objectives as the standard of competence, basic competence, and the indicator is the responsibility of teachers to make it happen in the learning activities. Given the formulation of these goals, particularly in the formulation of indicators include the delivery of a series of historical materials to the students, then the formulation of learning objectives will greatly affect the other components, such as learning strategies, media, materials and evaluation tools. Thus, weaknesses in teaching history in schools are systemic, therefore, to fix it also must be systemic too.

\section{History Learning Framework}

In this paper seeks to develop models of learning history as a manifestation of the reform of history teaching in schools. The regulations, which as stated in the Regulation of the Minister of National Education (Ministerial Education), No. 22,23 , and 24 in 2006, that learning history is only given to high school students, while junior high and elementary school students are given the subjects of Social Sciences (IPS). In connection with this, the learning model has been developed in the history of history teaching in high school.

Implementation of the learning history at school should directed to the achievement of goals or mastery of competencies. The purpose of this history lesson has been often mentioned by experts. According to Meulen (1987) the purpose of learning history in schools is to: (a) participate in developing the personality and mental attitudes students, (b) increase awareness of a dimension that is very fundamental in human existence, namely the continuity of movement and transition continues continuously from the past into the future, (c) leads to the honesty and wisdom, and (d) instill love of the nation and the humanitarian attitude. Mohammad Ali (1963) argued that the purpose of history lessons in school, especially national history is to: (a) generate, develop, and maintain the spirit of nationalism, (b) arouse a desire to realize the ideals of nationality in all 
fields, (c) generate desire to learn the history of nationality as part of world history, (d) students' awareness about the ideals and the national struggle to realize the ideals of nation and state. In Regulation of the Minister of National Education No. 22 of 2006 on Content Standards, which are basic in the curriculum development unit level of education (SBC), explained that the subjects intended to make history at the high school students have the following capabilities: (a) build awareness of the importance of learners time and place that is a process of the past, present, and future, (b) critical power train students to correctly understand historical facts with a scientific approach and is based on scientific methodology, (c) foster an appreciation and respect for learners against civilization heritage as evidence of Indonesia in the past, (d) foster students understanding of the formation process of the Indonesian nation through a long history and still proceed until future, (e) foster self-awareness in students as part of the Indonesian people who have a sense of pride and love of country that could be implemented in various areas of life both nationally and internationally.

The purpose of learning history shows that the implementation of teaching history in schools is not merely convey a series of historical facts to the students, but rather to sensitize learners or evoke a sense of history and national consciousness of the young generation (Widja, 1989). According to Sartono Kartodirdjo (1990), historical consciousness and national consciousness will be much needed to evoke a sense of pride (pride) and a sense of obligation (a sense of responsibility and obligation), namely the responsibilities and obligations of each young generation to work together to foster and maintain the unity and integrity, the integrity of the nation, and national identity in the face of various challenges and trials and jointly conduct national development. In line with this opinion Ruslan Abdul Gani (1963), argued that historical consciousness is a mental attitude and state of mind which includes increased conscience of someone with wisdoms and policy to confront and reflect on past experiences. Taufik Abdullah (2001), explains that historical consciousness is the awareness that the past (the past) is history, that is not a mythology so that people can take the wisdom of history (the wisdom of history).

In order to realize the learning of history that could increase the awareness of history, according to Gunning (1978) learning history at school should be directed to membelajarkan concepts and intellectual skills. In learning history is not merely telling a story and struggles of the past figures, but it should be applied to various learning strategies that allow students to appreciation and find the values of historical events and apply them in everyday life. With the process of learning history is not applicable concept "learning history" but "learn from history."

In the chart shows that awareness of history is formed when learners have found the values of historical events and apply them in everyday life. The values of these historical events would be obtained if the person doing the understanding of an event and this appreciation will occur a person has an understanding of 
the event. Understanding and appreciation for someone to an event would be obtained if the person is present and experiencing the event. In the process of learning history, this condition can not be implemented, because of events in history are learned einmaligh, which occur once and will never be repeated. Such incidents leave only footprints and traces of this heritage can be studied and learned. Therefore, steps can be taken in the process of learning history is to bring historical events to the presence of students or in other words, help students to as if present in the historical events being studied.

Learning framework to develop the awareness of history that history can be described in the following chart.

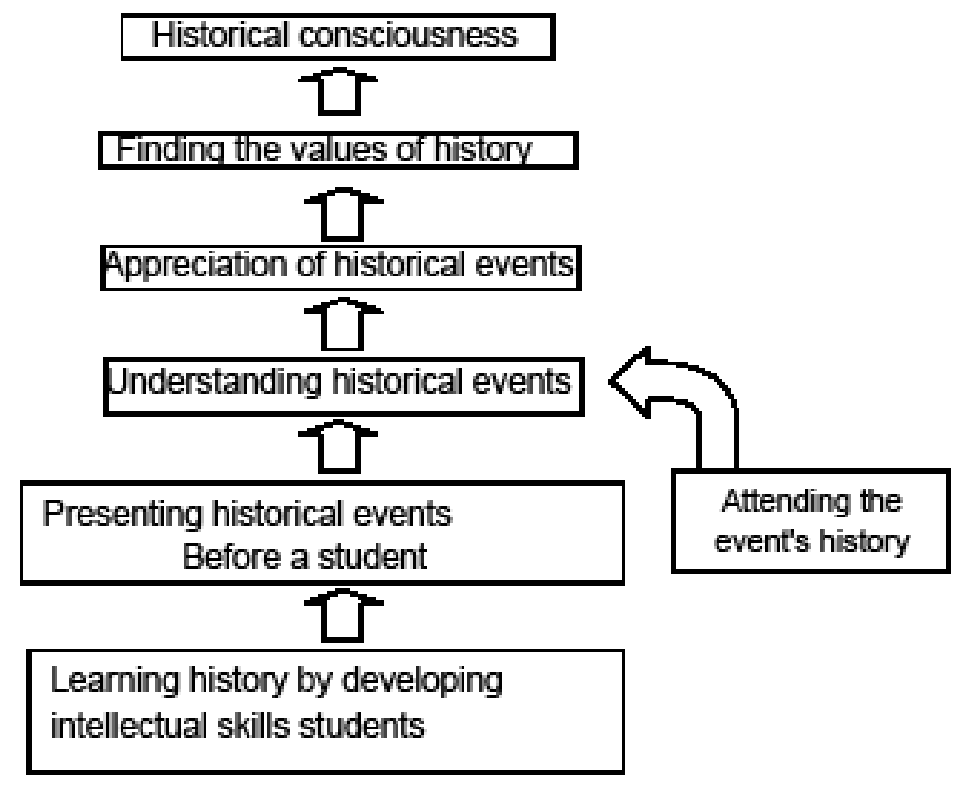

Image: Framework for Learning History

There are many ways that can be taken to bring historical events to the presence of students or help students as if present in the historical events that has been research. One way that can be taken is to apply the lessons that develop students' intellectual skills.

Intellectual skills is a mental procedure, the procedure that produces a principle as a new experience to solve a problem (Singer, 1980). According to Anderson and Krathwohl (2001) the purpose of intellectual skills capabilities more emphasis on mental processes in organizing an information materials either already owned (given) and studied (Remembered). In connection with the development of intellectual skills students bring Gagne (.........) detailed levels in the intellectual process that is composed of the lowest level to highest level. Levels are: (1) discrimination (discrimination), (2) the concept of concrete (concrete concept), (3) formulation concept (defined concept) (4) rule or Rule (rule), and (5) solving problems (problem solving .) Related to levels of understanding and intellectual skills are, in this history lesson more emphasis on efforts to train 
train students to solve various problems. In other words, in learning the history of attempts to train the highest level of student intellectual process, namely the ability to solve a problem. The performance of this stage is expected that learners can find and use complex rules to solve a problem.

The concept of learning by developing the intellectual skills is very suitable for application in school and always trained to learners. This is because in human life is always basically can not escape the problem. Somebody success in life will be determined by its ability to confront and solve the problems they face.

In the development of intellectual skills in school history lessons can be applied several methods, among others: (1) methods of inquiry or research, (2) application of Moral Dilemma Discussion (MDD), which was developed by Savage and Armstrong, (3) methods of solving problems (problem solving). Other methods that can be applied and associated with the development of intellectual skills students are brain storming, group discussion, giving the task, focus goup discussion (FGD), and field trips. Through these learning methods enable students to be directly involved in the assessment of historical events. Students are trained to learn to learn and study the historical events, so that will give the impression as if the student was present and witnessed the historical event being studied. This course will greatly facilitate the students to obtain a complete picture of historical events and conduct in-depth understanding and appreciation, which will further facilitate the students in finding their own meaning and value of historical events had learned to suit their needs. Thus through these learning activities learning objectives will be achieved maximally history.

In learning, the value discovery process takes a long time. In this case study does not emphasize on the number of values found in the students, but emphasized the value discovery process. If the pursuit of quantity, then the values of historical events can be quickly obtained by students in a way presented by the teacher, but this way is not through a process of appreciation, not likely to create self-awareness in students of history.

\section{Model of Learning History}

Based on the thought of learning the history of the above, then in its application in schools need to be translated into learning systems. Learning model developed by the history of this form of learning systems that include components of: (a) learning objectives, (b) teaching materials; (c) learning procedure, and (d) assessment. All components in the learning system is aimed at developing students' intellectual skills.

\section{Learning Objectives}

The purpose of learning has an important position, because the purpose will determine the direction and the entire learning activity. In the formulation of 
learning objectives should always pay attention to the existing hierarchy of goals, ie goals that are under the elaboration and menjunang achievement of objectives that are therein. In this case the hierarchy of learning objectives defined by outlining the history of the institution or purpose, known as institutional goals and objectives of national education. In this way, the learning system which will be developed regardless of the refractive goal.

Linked to the above, then the formulation of learning goals in high school history can not escape from the existing policy. Policies in force at this time, the purpose oflearning a subject has been formulated in Ministerial Education number 22 and 23 in 2006 in the form of learning objectives, standards of competence, basic competence, and standards for graduation (SKL). Given the formulation of learning objectives, standards of competence and basic competence as stated in Ministerial Education No. 22 of 2006 and the formulation of SKL as stipulated in the Ministerial Education number 23 in 2006 limited support for the effective implementation of learning history. Therefore in this paper seeks to review and refinement.

Based on the conditions, study the history of conceptual learning, and the provisions of the existing policy, the purpose of learning history that includes learningobjectives,standardsofcompetence, basiccompetence, and SKLasfollows. a. Learning History Objectives

Learning Objectives History in schools is so that learners have the ability:

1) build awareness of students about the importance of time and place that is a process of the past, present, and future.

2) critical power train learners to understand the facts of history is correctly based on scientific approach and scientific methodology.

3) foster an appreciation and respect for heritage learners of the Indonesian nation as evidence of civilization in the past.

4) foster students understanding of the formation process of the Indonesian nation through a long history and still proceed until the present and the future.

5) foster self-awareness in students as citizens of Indonesia are able to apply the values of past events in everyday life.

\section{b. Standards and Elementary Competency History Lesson}

With starting point in the formulation of standards of competence and basic competence as stated in Ministerial Education No. 22 of 2006 and the function of learning history, it should be in teaching history in high school do not need to distinguish the basic standards of competence and competence among students program science, social studies programs, and program language. In this case the subject of history given in high school should be in the form of "history education", and thus no distinction standard of competence, basic competence, and time allocation among the three majors. The formulation of standards of competence and basic competence historical subjects as follows. 
SURANTO,

Reformation in Learning History

Table 4.1 Competency Standards and Basic Competence

\begin{tabular}{|c|c|}
\hline \multirow{2}{*}{\multicolumn{2}{|c|}{$\begin{array}{lr}\text { Basic Competence } \\
\text { Class X }\end{array}$}} \\
\hline & Class X, Semester 1 \\
\hline $\begin{array}{l}\text { 1. Analyzing and } \\
\text { criticizing the basic } \\
\text { principles of science } \\
\text { history }\end{array}$ & $\begin{array}{l}\text { 1.1 Analyzing the characteristics of science history } \\
\text { 1.2 Using the basic principles of historiography }\end{array}$ \\
\hline \multicolumn{2}{|r|}{ Class X, Semester 2} \\
\hline $\begin{array}{l}\text { 2. Finding the } \\
\text { values of the early } \\
\text { civilizations of } \\
\text { Indonesia and the } \\
\text { world }\end{array}$ & $\begin{array}{l}\text { 2.1 Living with life of Indonesian society } \\
\text { 2.2 Analyze the early civilizations of the world community } \\
\text { that affect civilization Indonesia } \\
\text { 2.3 Analyzing the origins and spread of humans in the } \\
\text { Indonesian archipelago }\end{array}$ \\
\hline \multicolumn{2}{|r|}{ Class XI, Semester 1} \\
\hline $\begin{array}{l}\text { 1. Finding the values } \\
\text { of the development } \\
\text { of the traditional } \\
\text { countries of } \\
\text { Indonesia }\end{array}$ & \begin{tabular}{|l} 
0.1 Analyze the influence of religious development and the \\
Hindu-Buddhist culture on the lives of people in various \\
regions in Indonesia \\
o.2 \\
Analyze the influence of Islamic religious and cultural \\
developments on the lives of people in various regions in \\
Indonesia
\end{tabular} \\
\hline \multicolumn{2}{|r|}{ Class XI, Semester 2} \\
\hline $\begin{array}{l}\text { 2. Finding the values of } \\
\text { the development of } \\
\text { Indonesia since the } \\
\text { influx of Western } \\
\text { influence until the } \\
\text { Japanese occupation }\end{array}$ & $\begin{array}{l}\text { 1.1 Living and criticize people's lives in Indonesia during the } \\
\text { colonial period } \\
\text { 1.2 Analyze the relationship between the development of new } \\
\text { ideologies and social transformation in consciousness } \\
\text { and nationalist movement } \\
\text { 2.3 Living and criticize the Indonesian people's lives during } \\
\text { the Japanese military occupation }\end{array}$ \\
\hline $\begin{array}{l}\text { 3. Finding the values } \\
\text { of world history that } \\
\text { affect the nation's } \\
\text { history of Indonesia } \\
\text { from the } 18 \text { th } \\
\text { century until the } \\
\text { 2oth century }\end{array}$ & $\begin{array}{l}\text { 2.1 Analyzing the differences in the influence of the French } \\
\text { Revolution, American Revolution, and the Russian } \\
\text { Revolution to the development of the Indonesian } \\
\text { nationalist movement } \\
\text { 3.2 Analyze the influence of the industrial revolution in } \\
\text { Europe toward social change, economics, and politics in } \\
\text { Indonesia }\end{array}$ \\
\hline \multicolumn{2}{|r|}{ Class XII , Semester 1} \\
\hline $\begin{array}{l}\text { 1. Finding the values of } \\
\text { the Indonesian struggle } \\
\text { since the proclamation } \\
\text { until the birth of New } \\
\text { Order }\end{array}$ & $\begin{array}{l}\text { 0.1 Analyzing the events surrounding the proclamation of } \\
\text { August } 17,1945 \text { and the establishment of the Indonesian } \\
\text { government } \\
\text { o.2 Analyzing the financial-economic developments and } \\
\text { politics in the early days of independence until the year } \\
\text { 1950 } \\
\text { o.3 Living with the struggle of the Indonesian nation in } \\
\neg \text { hankan maintain independence from the threat } \\
\text { of national disintegration, especially in the form of } \\
\text { upheaval and revolt (among others: PKI Madiun 1948, DI } \\
\text { / TII, Andi Aziz, RMS, PRRI, Permesta, G-30-S/PKI) }\end{array}$ \\
\hline
\end{tabular}




\begin{tabular}{|c|c|}
\hline $\begin{array}{l}\text { 2. Appreciate and find } \\
\text { the values of life of } \\
\text { the nation and the } \\
\text { Indonesian state } \\
\text { since the New Order } \\
\text { until the reform } \\
\text { period }\end{array}$ & $\begin{array}{l}\text { 2.1 Analyze the development of the New Order government } \\
\text { 2.2 Analyzing the expiration of the New Order government } \\
\text { and the reform } \\
\text { 2.3 Living with political and economic developments and } \\
\text { changes in Indonesian society in the reform period }\end{array}$ \\
\hline \multicolumn{2}{|r|}{ Class XII , Semester 2} \\
\hline $\begin{array}{l}\text { 3. Finding the values } \\
\text { of the development } \\
\text { of world history } \\
\text { since World War } \\
\text { II until recent } \\
\text { developments and } \\
\text { their effects on the } \\
\text { lives of Indonesia }\end{array}$ & $\begin{array}{l}\text { 3.1 analyze the development of world history and the position } \\
\text { of Indonesia in the international political and economic } \\
\text { changes after World War II until the end of the Cold War } \\
\text { 3.2 Analysing the latest developments of world history and } \\
\text { its influence on the life of the Indonesian nation }\end{array}$ \\
\hline
\end{tabular}

3). Graduation Standards (SKL) History Lesson

Graduation Standards (SKL), as reflected in the Ministerial Education No. 23 of 2006 is a scoring guide in determining the graduation of students. In accordance with the role and position, it is possible will become the main reference for the teachers in performing their duties. In a study of government policy, showed that subjects SKL is not appropriate and need to be perfected. To ensure more effective learning, then SKL historical subjects need to be formulated as follows.

a) To analyze and criticize the basic principles of science history.

b) Find the values of the early civilizations of Indonesia and the world

c) Find the values of the development of the traditional countries of Indonesia.

d) Find the values of the development of Indonesia since the influx of Western influence until the Japanese occupation.

e) Find the values of world history that affect the nation's history of Indonesia from the 18th century until the 2oth century.

f) Find the values of the Indonesian struggle since the proclamation until the birth of the New Order.

g) Find the values of life of the nation and the Indonesian state since the New Order until the period of reform.

h) Find the values of the development of world history since World War II until recent developments and their effects on the life of the Indonesian nation.

\section{4). Translation Learning Objectives}

Learning objectives have been formulated on the Competency Standards (SK) and Basic Competency (KD) is the minimum standard set by the government and still general in nature, therefore, the educators were given the authority to develop and translate it more detailed. In penjabarannya certainly be distorted and contrary to the objectives that have been there. 


\section{Learning Procedure}

The procedure of learning or more commonly known as the learning method is a way to achieve learning outcomes in specific learning conditions. By basing the opinion Reigeluth (1983), methods which are part of the learning system includes three types, namely: (a) the strategy of organizing the material, (b) delivery of content strategy, and (c) management strategies.

1) The strategy of organizing the material

System of organizing the material in this history lesson is a thematic model, namely the learning carried out by examining certain themes in accordance with learning objectives to be achieved, namely the standard of competence and basic competence. Selection of themes, in addition to tailored to the objectives to be achieved is also based on the following considerations: (1) the element of closeness, both closeness and proximity of time, meaning that the selected theme is a theme that just happened and it happened at a place close to the learners; theme themes that were examined is then pulled back to study the history of similar events, (2) actual, in accordance with the principle of proximity, especially the related in the sense of time, the themes that were examined should be the actual themes, which is a theme that is being much talked about; (3) contextual, and is chosen themes appropriate to the child's life or society. By paying attention to these things, it is expected that the implementation of the learning history to be interesting.

The theme will be studied in each learning activity packaged in the form of challenging problems to be solved. Selection and determination that will be studied this problem should be performed by students under the guidance of teachers. In this case the teacher acting as organizers, facilitators, and motivators, which is organizing the environment and the situation by arguing that there are phenomena that can stimulate students to discover challenging problems to be studied. Thus the implementation of the learning process in the form of an intellectual skill to train students to learn to solve problems using scientific procedures, that is collecting information / data from various sources, analyze, discuss, make decisions, and publish it either orally or in writing.

In this model the subject matter students are organized not to be memorized, but as a material argument to solve the problem. Subject matter is a means to an end and not the purpose of learning, so not all the material of history is told in a complete and chronological to the students, but only selected materials that are essential to solve the problem. In this variety of materials and information from various sources can be used to solve the problem, allowing students to examine historical events using a multidimensional approach, multidiscipline, and obtain a holistic picture.

Based on the description of the learning procedure mentioned above, the many strategies of organizing material that can be applied to teachers. The strategy such as: student worksheet (LKS), a module that provides an overview of historical events that stimulate the emergence of various problems to be studied, 
textbooks that contain in-depth review of the events of history or the struggle of a character, story books in the direction of which is packaged in a novel, and hypertext, which is a collection of teaching materials and various writings about the events of history that is packed with technology utilizing computer / internet that allows students to track information to the internet.

\section{2) strategy to deliver material}

Based the description of the learning procedure mentioned above, the strategy of delivery of material that can be done is learning in the classroom, outside the classroom, and can also be done outside of school. Learning outside the classroom and outside of school do in order to collect data / information from various sources, such as libraries, internet, interviews, and observe the history or heritage museums. Thus, learning media, teachers and material resources is a major part in the strategy to deliver the content of this history lesson learning model.

In the selection of instructional media sources and is tailored to the problems that will be studied, the availability and the ability of schools, students and environmental conditions. The learning resources that can be used, among others: (a) a book or library, (b) internet or multimedia, (c) the character actors of history or society, (d) heritage / museum. Learning media that can be used, among others: VCD, television, computer, LCD, OHP, drawings, models, models or mock-many-objects.

\section{3). Management strategy}

Developed Learning model history this is a learning model to train and develop the intellectual skills of students. As for the steps that can be applied in developing the intellectual skills of these students are as follows.

a) encourage students to find problems in event history

b) collect data / information, either a group or an individual from various sources, such as books, internet, interviews, historical heritage / museum.

c) conduct the analysis and discussion groups to solve problems .

d) conduct class discussions.

e) conclusion and an affirmation of teachers.

f) make individual papers that reflect the application of the values of historical events studied in everyday life.

Based on the steps above, then the management learning strategy is a strategy used by individuals, groups, and classical. Individual learning is done in an effort to train self-reliance, responsibility and intellectual skills of students, while learning classical groups and conducted to train together and stimulate students in developing intellectual skills. Application of management strategies in this model are as follows. 
SURANTO,

Reformation in Learning History

Table 4.2: Strategic Management of Learning History

\begin{tabular}{|c|l|l|}
\hline No & \multicolumn{1}{|c|}{ Activities } & \multicolumn{1}{c|}{ Management Strategy } \\
\hline 1 & Define Problems & Classic \\
\hline 2 & Data Collection & Individual, Group \\
\hline 3 & Analysis & Indivivual, Group \\
\hline 4 & Discussion & Group, Classic \\
\hline 5 & Conduct Report & Individual, Group \\
\hline
\end{tabular}

In a learning model that develops students' intellectual skills can be applied several learning methods, such as: (a) the method of problems solving (problem solving), (b) research methods (inquiry), (c) approach to discussions of moral dilemmas (Moral Dilemma Discussion). All three methods have different characteristics, but have in common is that it can develop students' intellectual skills and also in accordance with the characteristics of the constructivist approach. All three of these methods can be used vary according to the characteristics of the problems assessed and goals to be achieved.

c. Rating

Assessment is an integral part of the learning system, because through the assessment of learning outcomes will be known. With reference to the Reigeluth (1983) opinion, learning outcomes can classified into three categories: (1) effectiveness, (2) efficiency, and (3) attractiveness of learning. The effectiveness of a learning measured by the level of student learning achievement, learning efficiency is measured by the effectiveness of time, cost, and effort required to organize learning, while the attraction of learning is measured by students' desire and inclination to learn more and continue their studies to a higher level.

In accordance with the three categories of learning outcomes mentioned above, then the model of learning system is the assessment of the assessment process and results. The assessment results are intended to determine achievement of learning objectives, namely the standard of competence and basic competence, while the assessment process is intended to examine the effectiveness of learning is done, and attractiveness of learning.

Types of bills made in learning the history of this form of individual tasks, group work, performance, attitudes, daily tests, mid semester, and repeat the semester. The shape of the instrument used in the form of written reports, portfolios, questionnaires, check lists, and written test. Through this type of assessment will be able to uncover the original conditions of students who are learning outcomes. Thus the appeal of students towards learning the history and the impetus to learn more will be revealed. Similarly, indicators that reflect the level of historical awareness is also possible students will be exposed. 
1) The written report

The written report is the report made by an individual student or group to solve a problem that has been determined together. This report was written after going through the process of collecting data / information, analysis and discussion groups. In data collection can be done from various sources, such as libraries, internet, observation of historical or museum, and interviews with resource persons or actors of history. Written reports from each student or group is then discussed in class discussions.

2) Portfolio

Portfolio is an original work of students in the form of paper. In making this portfolio teacher gave absolute freedom to the students write down all the thoughts, views, ideas, and attitudes associated with the new problems studied, the portfolio will reflect the original conditions of students who are learning the history.

To guarantee and promote freedom in expressing his writing students, the valuation of the portfolio is not an appraisal right or wrong as in the assessment of a written test. In this case the portfolio assessment conducted by an assessment rubric, namely the assessment of various components by giving a score on each component.

With this assessment enabled students to really feel free of opinion and not afraid either. It is very important to train students to express opinions, argue, and encouraged to conduct in-depth assessment of various fenomona or historical events using the rules of science. In this way will really allow students to gain an understanding in depth, receptiveness, find the values of various historical events, and able to behave or act in applying the values of history.

\section{3) Questionnaire}

Questionnaires are used to uncover the interests and interest in learning the history and the level of awareness of history students. Questionnaire can be done at each end of the meeting, means of improving the learning activities that teachers do, but because of considerations busy teachers, conducted at least one end of each learning basic competence. In addition to considerations busy teachers, specifically to determine the interest and attraction for students to the learning of history has been done through observation on each learning activity, whereas the level of awareness of history can be viewed on the portfolio task.

\section{4) Check list}

Check list used in the execution of observation of learning activities. Observations performed on each learning activity, namely as a means to determine the level of activity, participation, enthusiasm, cooperation, ability and depth of argumentation students in a discussion. These are the indicators of interest and the interest in students towards learning history. 
The observation results are very important, which is used as a means of evaluation or assessment of the effectiveness of learning and further used as a basis for changing the teaching methods used by teachers.

\section{5) The written test}

The written test is one of learning assessment tools. Written test that is used in the model of learning this history is the kind of tests that can measure the achievement of learning objectives, namely to uncover students' level of competence as defined in the standards of competence and basic competence. Based on these considerations, the type that matches the written test is a subjective test. This test is used to uncover all the competence and ability as a result of learning outcomes, especially its ability to analyze and criticize the historical events until the discovery of the values of that historic event.

Learning model is an alternative learning history of systemic reform. With these models are expected to increase the effectiveness of learning history and regardless of the slump. Although the learning model has been through the trial process, but the effectiveness influenced by other factors outside the system learning model. Therefore, in implementing the reform of history teaching in schools, there are two urgent to be addressed immediately, that mindset about learning the history and unity of all the steps related to the implementation of learning in school history.

First, the mindset about teaching history in schools that have so far is that: "The lesson of history is the subject matter Submitting history, both the history of Indonesian and world history". This kind of mindset has to burden the teachers memperpuruk history and learning history at school. It is said to burden, because the material feels very extensive history, while the allocation of limited time available. This is a heavy burden, which should deliver the subject matter that so many students in a very short time. These conditions are less favorable consequences for the implementation of learning history in school, because of steps taken by the teachers are simply submit items for the sake of chasing the target of existing curriculum. In the process of learning history there was never any appreciation process and there are only the memorization process, resulting in addition to learning goals are not achieved, subjects also sejaran become a boring subject.

Changed mindset, the terms used are not learning history, but learn from history. The process of learning history is not a process to submit a series of historical materials to the students, but efforts to encourage students to learn, researching and analyzing various historical events to get the values of these historical events. Thus the implementation of the learning history will be more attractive, growing interest in learning more, and it is possible that the learning objectives will be achieved.

Second, the unity of steps from all parties related to the implementation of learning in school history. Unity is very needed step in the reform of history 
teaching. In this case closely related to the mindset of learning history. Teachers are often less able to correctly apply the lessons of history because bernagai bound by policies that are less supportive. Awareness of teaching staff, learning the history of history to carry out correctly would be useless without the support of the parties involved, such as school principals, school supervisors, and all parties associated with policy-makers, both at the district / municipal, provincial, or central.

As an example of lack of unity step in education reform in Indonesia is in the implementation of educational curriculum unit level (SBC), especially history subjects. In this case the teacher should have the freedom to develop curriculum according to the Ministerial Basic Education, shackled by the issuance of government syllabus. Whatever the reason, teachers should follow the existing examples, although examples are not in line with the concept of learning history, which is subject oriented matters.

\section{Learning Methods for the Development of Intellectual Skills Students}

In developing the intellectual skills of students, learning of history in schools can be used various learning methods, such as: (1) methods of inquiry or research, (2) application of Moral Dilemma Discussion (MDD), which was developed by Savage and Armstrong, (3) problem solving methods ( problem solving). Other methods that can be applied and associated with the development of intellectual skills students are brain storming, group discussion, giving the task, focus goup discussion (FGD), and field trips. With these learning methods enable students to be directly involved in the assessment of historical events. Students are trained to learn to learn and study the historical events, so that will give students the impression as if the present historical events that were examined. This course will greatly facilitate the learners to obtain a complete picture of historical events and conduct in-depth understanding and appreciation, which will further facilitate the students in finding their own meaning and value of historical events being studied according to their needs. Thus through these learning activities learning objectives will be achieved maximally history.

As an illustration, the following will be explained the rational application of inquiri or research methods, problem solving and MDD in the development of intellectual skills.

Inquiry is a research-based learning methods and through inquiry to develop a personality attitude. This is as disclosed Beyer (1979), that the attitude and personality that develops with inquiry learning, among others doubt the truth that has been long and want to know something new, appreciate the reasoning as a way to gain a truth, to appreciate the data as a tool to test the truth, objective examination of existing data and to avoid prejudice, willing to accept the provisional decision before getting the truth. 
Inquiry is a strategy in the learning process-oriented, that focuses on students' skills in solving problems and finding information (Cleaf, 1991). This is in line with the opinion of Bruce Joyce, Marsha Weil and Calhoun (2009) who said that the inquiry is based on freedom and with the participation of learners actively in solving the problem scientifically. According to Ellis (1977), the main contribution to learning by inquiry method is offered an opportunity for learners to engage in the process of getting an in-depth knowledge through contact with information, so as to obtain an important perspective from which to read and seen. In accordance with the process, then learning inquiri grouped into developing thinking skills (Savage and Armstrong, 1996).

According to Welton and Mallan (1988), the proceedings are preceded by an awareness of the problem, the definition of the problem, data collection, proposed hypotheses, test hypotheses, draw conclusions, and ends with testing the conclusion.

Inquiry method as a form of development is appropriate intellectual skills students apply in learning history. The idea of applying the inquiry method of learning the real history is not a new thing. In addition Gunning suggested the application of intellectual skills in learning the history, some leaders like Sartono Kartodirjo, Djoko Suryo suggested that applied research methods in teaching history.

Research method is a step in the work of historians doing research and writing of history. Historians acknowledge that the application of these research methods, learning history more interesting and allow learners to better appreciate the various historical events.

The steps in research methods in teaching history is essentially the same as the steps in the inquiry method. Application of the inquiry method or methods of research in learning history can be made for the entire event sejaran. Application of research methods in teaching history is to provide a task that is directed at efforts to train students to solve various problems of historical events that allow students to gain an understanding and pengahayatan of historical events and further discover their own values of historical events.

Method of problem solving learning (problem solving) can be interpreted as a series of learning activities that emphasize the process of solving scientific problems. In a method of solving the problem trying to persuade more students to use reasoning in mememecahkan problems. This was as where proposed by Savage and Armstrong (1996), that problem-solving method used in a way to give the students a problem to be solved. Through the method of solving this problem is expected students able to resolve the case by a good argument with facts and data form the basis of rationality. The learning process by using the method of solving this problem is often known as problem-based learning (problem base learning).

Problem-solving method can be applied in teaching history in schools. This is because in learning the history of many problems that need to be solved, especially problems related to actual problems that developed in the community. In 
the process of solving this problem will encourage students to gain understanding and pengahayatan of historical events which will further enable students to discover their own values of historical events. This problem solving method can be applied to almost any history of learning objectives.

Moral dilemma discussion is a learning approach which is done by raising the issue of a dilemma related to the values and morals (Tom V Savege, \& David G. Armstrong, 1996). The ultimate goal of using this approach is that the values or morals are internalized in more students who applied in everyday life.

Moral dilemma discussions (MDD) was developed based on the results of Kohlberg's research using the instrument case "Heinz Moral Dilemma." The study tried to reveal the person's moral level, Kohlberg presents the stories of moral dilemmas and then provide questions that stimulate the respondent to provide moral decisions and perform certain actions in accordance with the situation told in such a moral dilemma.

In reviewing the discussion of moral dilemmas, the students were given freedom and stimulated to mengemukankan opinions, respond, and provide moral decisions in accordance with the problems under study. In this way it will unfold one's level of moral reasoning. Therefore, according to Kohlberg's moral dilemma discussions can be used to see one's level of moral reasoning, but also at the same time can be used to improve it. Through discussions of moral dilemmas are expected to train the moral sensitivity, moral assessment, moral decision making, and further moral action.

Given the MDD is an effective means to implement the value of education especially in schools and in learning the history also contained a variety of values and value menupakan education facilities, the MDD is also possible to apply the lessons of history. Relative to those in this study tried to adopt and apply the MDD in learning history at school. In this case, of course, not all historical events can be assessed by using MDD. Therefore, in applying MDD is done by choosing certain themes of historical events that contain moral issues. As for the steps that can be achieved in the implementation of the MDD is as follows. First, introduce the issues of moral dilemmas in historical events related to student life. In this case can be used prose story that has been prepared teachers, the news in newspapers or other mass media, video playback, or tape recorder. Issues of this moral dilemma can also come from students who share the experience of his life. Moral dilemmas in the delivery issue concludes with questions that stimulate students to make choices, provide a moral decision and the reasons on which there is a moral dilemma. Second, students are asked to provide feedback, provide their moral decisions in a short paper alasanannya. The work of these student papers will be used as one consideration in determining the stage of moral reasoning development of students. Third, students are asked to submit responses while the moral dilemma presented in accordance with the results of their writing. Fourth, divide the group and dilajutkan discussion group for moral decision and the reasons. Fifth, conduct class discussions draw conclusions. 
Application of MDD in the development of history teaching models will be strongly influenced by the ability of teachers, namely the ability to choose and raise issues of historical events related to values and morals.

\section{Conclusion}

Learning history in school Naturalife Greenworld a very important role, both for the formation of one's personal as well as in supporting the continuity of the life of nation and state, therefore the government always trying to improve the quality and effectiveness of implementation. These efforts are reflected in the presence of several school curriculum renewal, fulfillment of the various facilities, infrastructure and instructional media, and increased professionalism of teachers. These efforts appear to have not shown significant results, proved less of a national consciousness of the citizens of the nation, corruption of state officials, and the threat of national disintegration, and even the implementation of teaching history in schools is considered boring and underestimated students. In connection with this it is necessarily to review and restructuring of learning in school history that the article is called reform.

Reformation in learning history by learning the implementation of systemic reforms, comprehensive, and fundamental to apply the learning model that develops students' intellectual skills. In addition, there needs to be efforts to change the mindset about the history and the unification step pembalajaran from all parties involved in the learning process to jointly have a fix execution pembelajara embroidery history. Renewal learning is done by reviewing the history of all components associated with the process of learning, ie learning objectives, materials, media, procedures for implementation of learning and assessment system. All these components should be geared towards the development of intellectual skills of students. In this way other than the implementation of learning and history attract become more challenging, will also enable students to gain an understanding, appreciation, and feel as if present at the event under study. More information is expected students will find the values of the historical events that were examined and have a sense of history.

In developing the intellectual skills of learning in school history this can be used several methods of learning, such as methods of solving problems (problem solving), methods of research (inquiry), and approach the discussion of moral dilemmas (Moral Dilemma Discussion).

\section{REFERENCES}

Abdulgani, R. (1963). Penggunaan Ilmu Sejarah. Bandung: Prapanca, Abdullah,T. (2001). Nasionalisme dan Sejarah. Bandung: Satya Historika. 
Ali, R. M. (1963). Pengantar Ilmu Sejarah Indonesia. Jakarta : Bhratara.

Anderson, O. W. \& David K. (2001). A Taxonomy for Learning, Teaching and Assessing. New York: Longman Inc.

Beyer, B.K. (1979). Inquiry in the Social Studies Classroom: A. Strategy for Teaching.Colombus OH: Charles E.. Merril Publ.Co.

Budhisantoso, S. (1985). "Kesadaran Sejarah dalam Pengembangan Kebudayaan Nasional Indonesia", dalam Pemikiran tentang Pembinaan Kesadaran Sejarah. Jakarta: Debdikbud Direktorat Sejarah dan Nilai Tradisional.

Cleaf, D.W.V. (1991). Action in Elementary Social Studies. Boston: Allyn and Bacon.

Ellis, A.K. (1977). Teaching and Learning Elementary Social Studies. London: Allyn and Bacon Inc.

Gunning, D. (1978). The Teaching of History. London : Croon Helm.

Joyce, B., Marsha W. and Calhoun. (2009). Models of Teaching. Boston: Pearson Education Inc.

Kartodirdjo, S. (1990). "Fungsi Sejarah dalam Pembangunan Bangsa, Kesadaran Sejarah, Identitas dan Kepribadian Nasional", Seminar Nasional V Sub Tema Pengajaran Sejarah, Jakarta: Depdikbud Direktorat Sejarah dan Nilai Tradisional Proyek Inventarisasi dan Dokumentasi Sejarah Nasional.

(1993). "Sejarah Nasional dan Pembangunan Bangsa", Pendekatan Ilmu Sosial dalam Metodologi Sejarah, Sartono Kartodirdjo. Jakarta : PT. Gramedia Pustaka Utama.

. (1993). Pendekatan Ilmu Sosial dalam Metodologi Sejarah. Jakarta: Gramedia,

Klooster, H.A.J. (1984). Bangsa Indonesia Menulis Sejarahnya Sendiri. Terjemahan Suhardi.Surakarta: Jurusan Sejarah Fak. Sastra UNS, 1992,

Kohlberg, L. The Psychology of Moral Development.. San Francisco: Harper \& Row Publisher.

Madjid, N. (1997). “Masyarakat dan Kesadaran Sejarah” Makalah Konggres Nasional Sejarah 1996.Jakarta: Debdikbud RI.

Marsh, C. \& Stafford,K.,(1988). Curriculum: Pactice and Issues, Roseville, Australia : McGraw-Hill.

Metcallf, L. E. (1971). Values Education: Rational, Strategy, and Procedure. Washington DC : NCSS.

Meulen SJ.,W.J. van der Ilmu Sejarah dan Filsafat. Yogyakarta : Kanisius, 1987.

Permen Diknas Nomor 22 tahun 2006

Reigeluth, C. M. (1983) Intructional-Design Theories and Model: An Overview of their Current Status. London, Lawrence Erlbaum Associates Publisers.

Rest (1983). "Morality", in Husen (Ed), Handbook of Child Psychology, Vol 4. New York: Wiley. 
SURANTO,

Reformation in Learning History

Savege, Tom V, \& David G. (1996). Amstrong, Efektif Teaching in Elementary Social Studies. New Jersey : Prentice-Hall.

Singer, R.N. Motor Learning and Human Performance. New York: McMillian Publishing Co.,1980.

Welton, D.A. \& J.T. Mallan. (1988). Children and the Weorld: Strategies for Teaching Social Studies. Boston: Hougton Mifflin co. 